\title{
Anaerobic Digestion and Codigestion of Chlorella Vulgaris Microalgae Biomass with Wastewater Sludge and Dairy Manure for Biogas Production
}

\author{
Saad H. Ammar* Sadiq Riyadh Khodhair** \\ *, **Department of Chemical Engineering/College of Engineering / Al-Nahrain University \\ *Email: saad_cheminet@yahoo.com \\ **Email: $\underline{\text { Sadqkn@gmail.com }}$
}

(Received 8 January 2017; Accepted 23 March 2017)

https://doi.org/10.22153/kej.2017.03.001

\begin{abstract}
Anaerobic digestion process of organic materials is biochemical decomposition process done by two types of digestion bacteria in the absence of oxygen resulting in the biogas production, which is produced as a waste product of digestion. The first type of bacteria is known as acidogenic which converts organic waste to fatty acids. The second type of bacteria is called methane creators or methanogenic which transforms the fatty acids to biogas $\left(\mathrm{CH}_{4}\right.$ and $\left.\mathrm{CO}_{2}\right)$. The considerable amounts of biodegradable constitutes such as carbohydrates, lipids and proteins present in the microalgae biomass make it a suitable substrate for the anaerobic digestion or even co-digested with other organic wastes. The present work investigated methane biogas production by anaerobic codigestion of microalgae, Chlorella vulgaris biomass with organic waste from several sources such as wastewater sludge and dairy manure waste in different proportions as an additional carbon supply to enhance anaerobic digestion and therefore biogas production. Six bottles, employed as batch biodigesters each of 1 liter capacity, were used for that purpose at moderate conditions $\left(35 \pm 2{ }^{\circ} \mathrm{C}\right)$. The produced biogas volume was monitored daily along 35 days and the results showed that the daily and cumulative biogas production was increased 4.5 times and 3 times for the bottles with $66.67 \%$ microalgae compared with the bottles with wastewater sludge or dairy manure waste only, respectively.
\end{abstract}

Keywords: Anaerobic codigestion, biogas; dairy manure, microalgae Chlorella Vulgaris, wastewater sludge.

\section{Introduction}

Anaerobic digestion is biological process, occurring naturally in which a group of anaerobic microorganisms convert organic substrates or biowaste into biogas containing methane $(\mathrm{CH} 4)$ and carbon dioxide $(\mathrm{CO} 2)$ which is used as a renewable energy source [1].Biogas energy provides a lot of advantages. The cost of electricity plants based on biogas is less than coal, oil, or nuclear power plants and be built quickly and simply. Biogas is a renewable resource compared with these other current energy sources. Biogas provides a superior source of energy that is beneficial to the environment $[1,2]$.

The bio-digestion of organic substances which contain mainly proteins, carbohydrates and fats takes place in four stages: hydrolysis, acidogenesis, acetogenesis and methanogenesis. In this process a series of microorganisms called acidogenic bacteria converts the organic wastes which contain carbohydrates, proteins, oils, and cellulose to short chain organic acids such as propionic, butyric and acetic acids and $\mathrm{CO}_{2}$ and $\mathrm{H}_{2}$ gases and then these organic acids are converted with $\mathrm{H}_{2}$ gas to biogas by another type of bacteria called methanogenic bacteria in the absence of oxygen [2].In more accurately, anaerobic digestion include more than two 
stages of biogas production and many biochemical reactions are take place in these stages (Fig.1). In the first stage, the large insoluble molecules (carbohydrates, proteins, oils, and cellulose) are hydrolyzed by enzyme catalyst which is provided by hydrolytic bacteria into more soluble small molecules like fatty and amino acids, and sugars. In the second stage (known as acidogenesis) these molecules are converted to smaller molecules such as carbonic acids, hydrogen, carbon dioxide, and ammonia. In the third stage (known as acetogenesis) carbonic acids are converted to acetic acids, $\mathrm{CO}_{2}$ and $\mathrm{H}_{2}$. Finally, the products from the third stage are converted to a mixture of $\mathrm{CH}_{4}$ and $\mathrm{CO}_{2}$ by the methanogenic bacteria [4], [5].

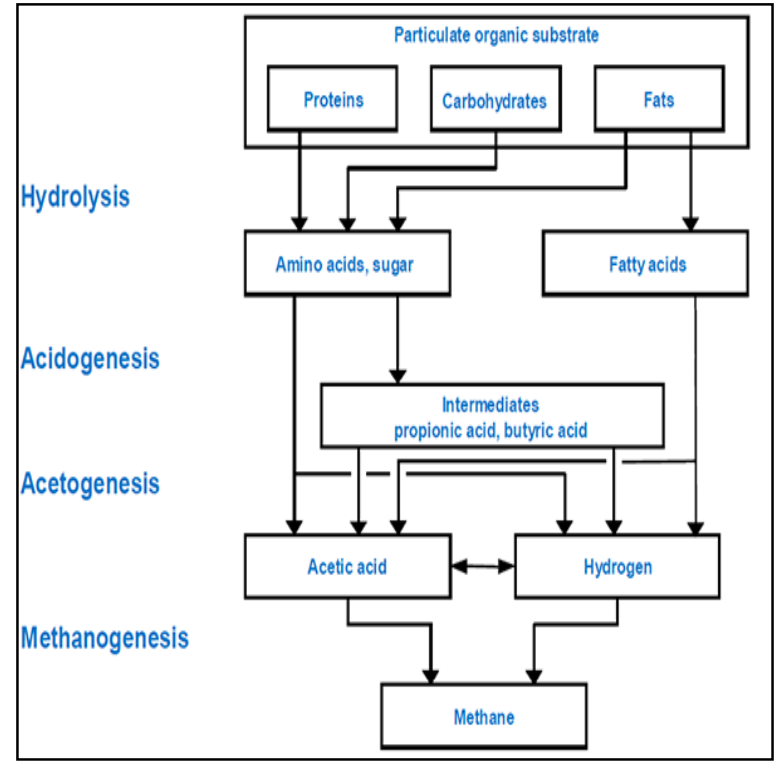

Fig. 1. Degradation steps of anaerobic digestion process [3].

The codigestion process is carried out when more than one substrate feedstock has been used simultaneously. Anaerobic digestion intrinsically became more stable when several types of substrates utilized at the same time are increased. The most common co-digestion systems include some major substrates like wastewater sludge or dairy manure waste with additional minor substrates of a single, or a variety of additional substrate like algae biomass, vegetable waste, whey, municipal sludge. etc. Several technological and economic advantages of anaerobic co-digestion can be reported such as improving the balance of nutrient $(\mathrm{C} / \mathrm{N}$ ratios in the biodigester), dilution of toxic compounds, enhancement the fluidity behavior of the single waste (i.e. make the digesting system more homogenous) and therefore increasing the biogas productivity [5], [6].

Microalgae received large attention as a biofuel feedstock as a result of its high productivity, low lignin content, the possibility of planting on non-arable grounds or in lakes and are able to produce large amounts of biomass as compared with other conventional crops such as soybean, corn, canola, jatropha, and coconut. The photosynthetic efficiency of microalgae may reach $5 \%$ of the solar energy compared to $2 \%$ for earthly plants [7].

Anaerobic digestion/codigestion of microalgae biomass has been widely used for that purpose because of high lipids, proteins and carbohydrates content in various amounts and different of these components affect the yield of biogas. In general, the lipids content in Chlorella Vulgarismicroalgae may reach up to $40 \%$ lipids by dry weight and this depends on the nutrients especially nitrogen content in the culturing media. It suggested by the most researchers such as Sialve, B. et al. [8] that the lipid content has great influence on the biomethane production, followed by proteins and then carbohydrates. Historically the first use of algae in the anaerobic digestion for biogas production was by Golueke, C. G. et al. in 1957 [9], who's used Scenedesmusspp. And Chlorella Spp. Species for that purpose and they compared the methane yield with other substance such as wastewater sludge at the same digestion temperature.

Depending on the environment and growth conditions, the freshwater Microalgae Chlorella Vulgaris have proportions of proteins, lipids and carbohydrates as (6-52 \%), (7-23\%) and (5$23 \%)$ respectively. The carbon-to-nitrogen ratio $(\mathrm{C} / \mathrm{N})$ ratio in Microalgae Chlorella Vulgaris is inversely proportional to protein content in these species and it is usually low compared with other terrestrial plants (10/1 for microalgae while it is 36/1 for terrestrial plants) [8].

Anaerobic digesting of high protein content microalgae (and therefore low $\mathrm{C} / \mathrm{N}$ ratio) could result in high total ammonia $\left(\mathrm{NH}_{4}{ }^{+}\right.$ions and free ammonia) accumulated and also high volatile fatty acids presented in the digester mixture [10]. High concentration of total ammonia and volatile fatty acids in the digesting mixture would decrease the activity of methanogenic bacteria and further accumulation of free ammonia could fail the anaerobic digestion process, this is called ammonium toxicity where the unionized hydrophobic (free) ammonia 
diffuses passively across the cell membranes of methanogenic bacteria (which is have high sensitivity to ammonia presence among the other bacteria hydrolytic, acidogenesis and acetogenesis) causing proton imbalance or potassium lack where it expresses its toxicity [11]. It can adopt several ways to avoid the impact of low $\mathrm{C} / \mathrm{N}$ ratios, one method to avoid excessive ammonia accumulation and therefore improving the performance of digestion process is to increase the $\mathrm{C} / \mathrm{N}$ ratios by adding high carbon (and low protein) content materials as co-substrates to the digester [12]. This rule has attracted us to investigate the ability of wastewater sludge and dairy manure waste as high $\mathrm{C} / \mathrm{N}$ ratio substrates for biogas production when co-digested with microalgae Chlorella Vulgaris biomass.

In the present study, the Microalgae Chlorella Vulgarisbiomass wasbiodigested simultaneously with wastewater sludge and dairy manure waste in different quantities as an extra source of organic materials to enhance the biomethane yield.

\section{Experimental}

\subsection{Raw Materials}

Microalgae Chlorella Vulgarisbiomass provided from previous culture work by Ammar, S. H. in 2016 [13] cultured in 2.5-liter semi-continuous airlift photobioreactor using 80 $\mathrm{mg} / \mathrm{L}$ of 20:20:20+TE NPK as nutrients, 6 LPM air flowrate, photoperiod cycle of $20: 4 \mathrm{~h}, \mathrm{pH}$ of 6-7 and temperature of $22 \pm 1{ }^{\circ} \mathrm{C}$ for biomass production. The produced microalgae biomass concentration was $0.316 \mathrm{~g} / \mathrm{L}$ and then to be concentrated to $2.6 \mathrm{~g} / \mathrm{L}$ by centrifugation before used.

Dairy manure waste (DMW) was obtained from a local farm located in Al-Fudhaliyah region, east of Baghdad, Iraq. Wastewater sludge (WWS) was provided from the Environment and Water Department, Ministry of Science and Technology, Baghdad, Iraq. The water content in WWS was 5\%. After receiving, the WWS stored immediately in a fridge at about $5^{\circ} \mathrm{C}$ until be used. The WWS was diluted to $33 \%$ in water before digestion.

\subsection{Experimental Setup and Procedure}

Substrates codigestion experiments were conducted in six 1-liter glass bottles (each 750 $\mathrm{ml}$ working volume) as batch biodigesters placed in a water bath with constant temperature at $35 \pm 2{ }^{\circ} \mathrm{C}$. Each digester bottle was air tight by rubber septum, the outlet biogas from each digester was collected by $0.25 \mathrm{~L}$ glass bottle filled with water worked as biogas storage vessel. The amount of biogas produced was measured daily by using the water displacement method as shown in Fig.2. The experimental setup was viewed photographically in Fig.3. Each bioreactor was loaded with the feedstock systems as described in table (1). The wastewater sludge and dairy manure waste systems were diluted to $33 \%$ vol. in water before used. The methane and $\mathrm{CO}_{2}$ gases concentrations were measured by using GEM 5000 gas analyzer (Geotechnical instrumentals, Ltd. UK).

\section{Table 1,}

Proportions of feedstock systems used in this study $(\mathrm{M}=$ Microalgae of concentration $=2.6 \mathrm{~g} / \mathrm{L}$, WWS= Wastewater sludge, DMW = Dairy manure waste)

Digester No.

Run No. (Total reactor volume $=1 \mathrm{~L}$, working volume $=750 \mathrm{ml}$, substrate $(\mathrm{WWS}$ or DMW) $\%$ used $=33 \%$ vol., microalgae concentration used $=2.6 \mathrm{~g} / \mathrm{L}$ )

\begin{tabular}{|c|c|c|c|c|c|c|}
\hline & 1 & 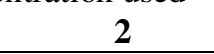 & 3 & 4 & 5 & 6 \\
\hline 1 & $500 \mathrm{ml} \mathrm{M}+$ & $375 \mathrm{ml} \mathrm{M}+$ & $250 \mathrm{ml} \mathrm{M}+$ & $100 \%,(33 \%$ vol. $)$ & \multirow{4}{*}{$\begin{array}{l}100 \% \mathrm{M} \text { (with } \\
2 \text { gm of } \\
\text { wastewater } \\
\text { sludge as } \\
\text { inoculum) }\end{array}$} & \multirow{4}{*}{$\begin{array}{l}500 \mathrm{ml} \mathrm{M}+ \\
125 \mathrm{ml} \mathrm{WWS} \\
+125 \mathrm{ml} \\
\text { DMW }\end{array}$} \\
\hline & $250 \mathrm{ml}$ DMW & $375 \mathrm{ml} \mathrm{DMW}$ & $500 \mathrm{ml} \mathrm{DMW}$ & $\begin{array}{l}\text { DMW ( } 250 \mathrm{ml} \\
\text { DMW + } 500 \mathrm{ml} \\
\text { water })\end{array}$ & & \\
\hline \multirow[t]{2}{*}{2} & $500 \mathrm{ml} \mathrm{M}+$ & $375 \mathrm{ml} \mathrm{M}+$ & $250 \mathrm{ml} \mathrm{M}+$ & $100 \%$ (33\%vol.) & & \\
\hline & $250 \mathrm{ml} \mathrm{WWS}$ & $375 \mathrm{ml} \mathrm{WWS}$ & $500 \mathrm{ml} \mathrm{WWS}$ & $\begin{array}{l}\text { WWS }(250 \mathrm{ml} \\
\text { WWS + } 500 \mathrm{ml} \\
\text { water })\end{array}$ & & \\
\hline
\end{tabular}




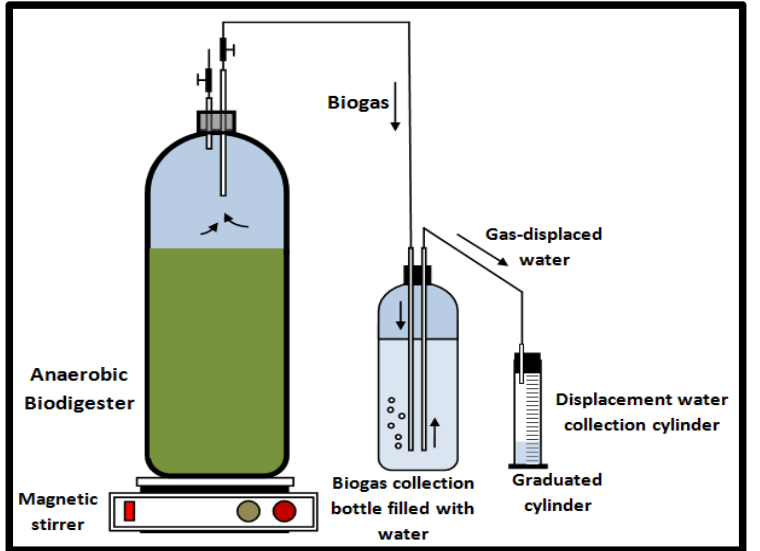

Fig. 2. Schematic diagram of one experimental bioreactor used for anaerobic co-digestion.

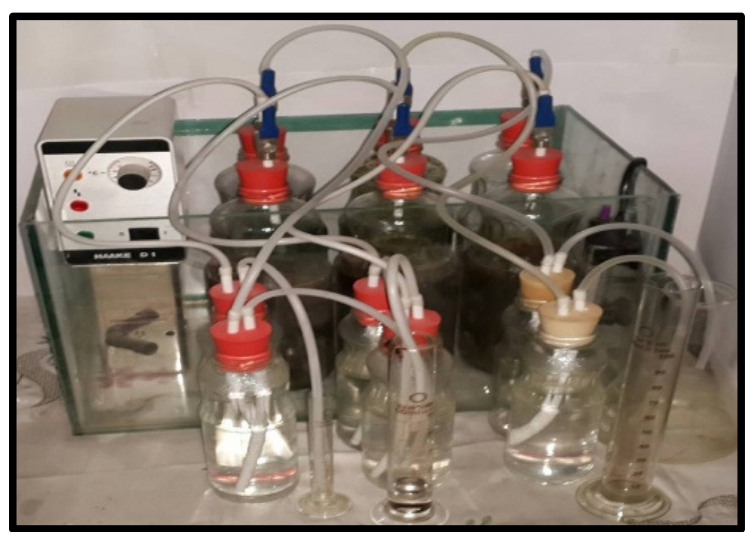

Fig. 3. Photographic view of the experimental bioreactors in use.

\section{Results and Discussion}

\subsection{Microalgae-Dairy Manure Waste System}

Fig.4 shows the results of MicroalgaeDiary manure system daily codigesting process (Fig.4 a) and cumulative biogas production (Fig.4 b) at different combinations of Microalgae in Cow manure system while Fig.5 shows the maximum biogas production for the five combinations of Microalgae in Dairy manure system. As shown in these figures, the total biogas production increased when using combined microalgae and dairy manure. The combination of $500 \mathrm{ml}$ microalgae and $250 \mathrm{ml}$ dairy manure waste give higher biogas yield than other combinations resulting in a biogas production of $1671 \mathrm{~mL}$ composed by $43 \%$ of methane at day 30 as listed in Table 2. The maximum efficiency of daily biogas and methane production was observed in $6^{\text {th }}$ and $8^{\text {th }}$ day (two peaks) of the $500 \mathrm{ml} \mathrm{M}+250 \mathrm{ml}$ DMW combination (Figs 4.a and 5.a).

Table 2,

Total biogas and methane yields from microalgaedairy manure waste system at day-30.

\begin{tabular}{llll}
\hline $\begin{array}{l}\text { System } \\
\text { composition }\end{array}$ & $\begin{array}{l}\text { Total } \\
\text { biogas } \\
\text { volume } \\
(\mathbf{m l})\end{array}$ & $\begin{array}{l}\text { Methane } \\
\text { volume } \\
(\mathbf{m l})\end{array}$ & $\begin{array}{l}\text { Methane } \\
\%\end{array}$ \\
\hline $750 \mathrm{ml} \mathrm{M}$ & 147 & 95 & 64.8 \\
$750 \mathrm{ml} \mathrm{DMW}$ & 557 & 300 & 54 \\
$\begin{array}{l}250 \mathrm{ml} \mathrm{M}+500 \\
\mathrm{ml} \mathrm{DMW}\end{array}$ & 838 & 450 & 53.6 \\
$\begin{array}{l}375 \mathrm{ml} \mathrm{M}+375 \\
\mathrm{ml} \mathrm{DMW}\end{array}$ & 907 & 543 & 59.8 \\
$\begin{array}{l}500 \mathrm{ml} \mathrm{M}+250 \\
\mathrm{ml} \mathrm{DMW}\end{array}$ & 1671 & 719 & 43 \\
\hline
\end{tabular}
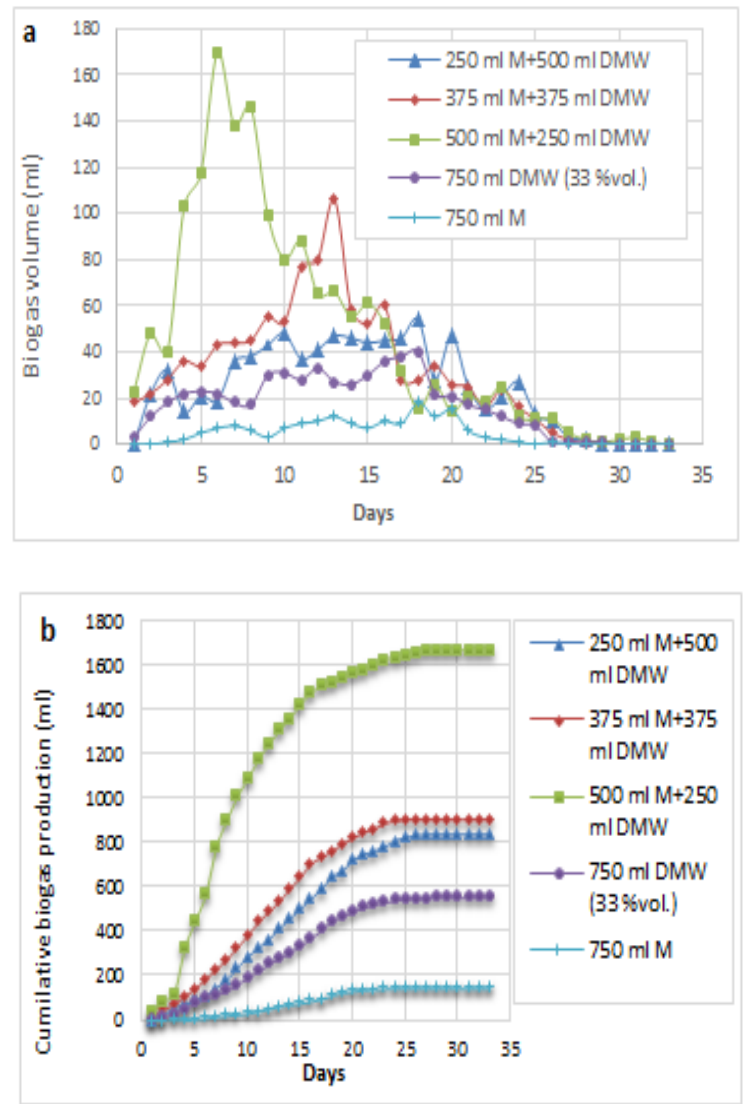

Fig. 4. Daily (a) and Cumulative (b) biogas production (ml) for codigestion of Microalgae-Dairy manure waste system. 

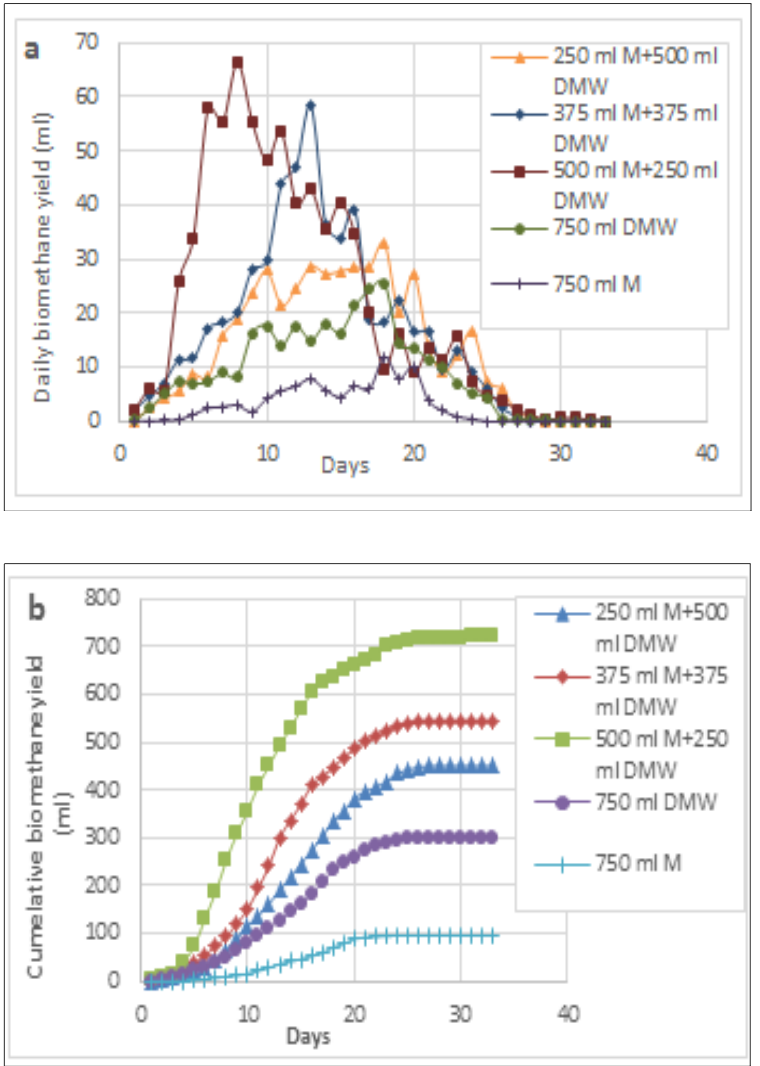

Fig. 5. Daily (a) and cumulative (b) biomethane production for codigestion of Microalgae-Dairy manure waste system.

\subsection{Microalgae-Wastewater Sludge System}

Fig.6 shows the daily (a) and cumulative (b) biogas production of Microalgae - Wastewater sludge codigesting process which included five combinations while Fig.7 shows daily methane production. It is clear also that whenincreasing the microalgae percent, the daily biogas production increased. The maximum daily biogas yields were $68 \mathrm{ml}, 150 \mathrm{ml}$, and $300 \mathrm{ml}$ for $250 \mathrm{ml}$ microalgae $+500 \mathrm{ml}$ wastewater sludge, $375 \mathrm{ml}$ microalgae $+375 \mathrm{ml}$ wastewater sludge and $500 \mathrm{ml}$ microalgae $+250 \mathrm{ml}$ at the $13^{\text {th }}, 11^{\text {th }}$, and $6^{\text {th }}$ day respectively, i.e. biogas yield increase with increasing microalgae proportion in the microalgae-wastewater sludge system. These results were better when compared with microalgae- dairy manure waste system at the same proportions as shown in Figs. 8 and 9, this is specifically due to high carbon content present in wastewater sludge [2]. Table 3 show Total biogas and methane yields from microalgae- wastewater sludge system at day-30.
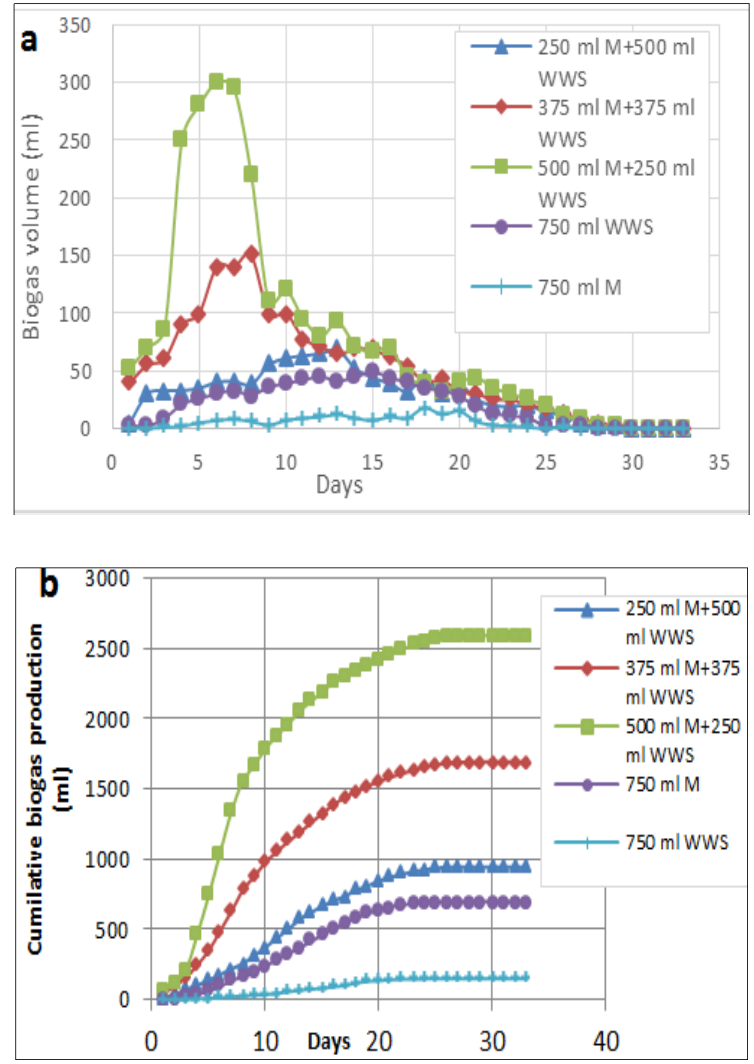

Fig. 6. Daily (a) and (b) Cumulative total biogas production (ml) for codigestion of MicroalgaeWastewater sludge (M+WWS) system.
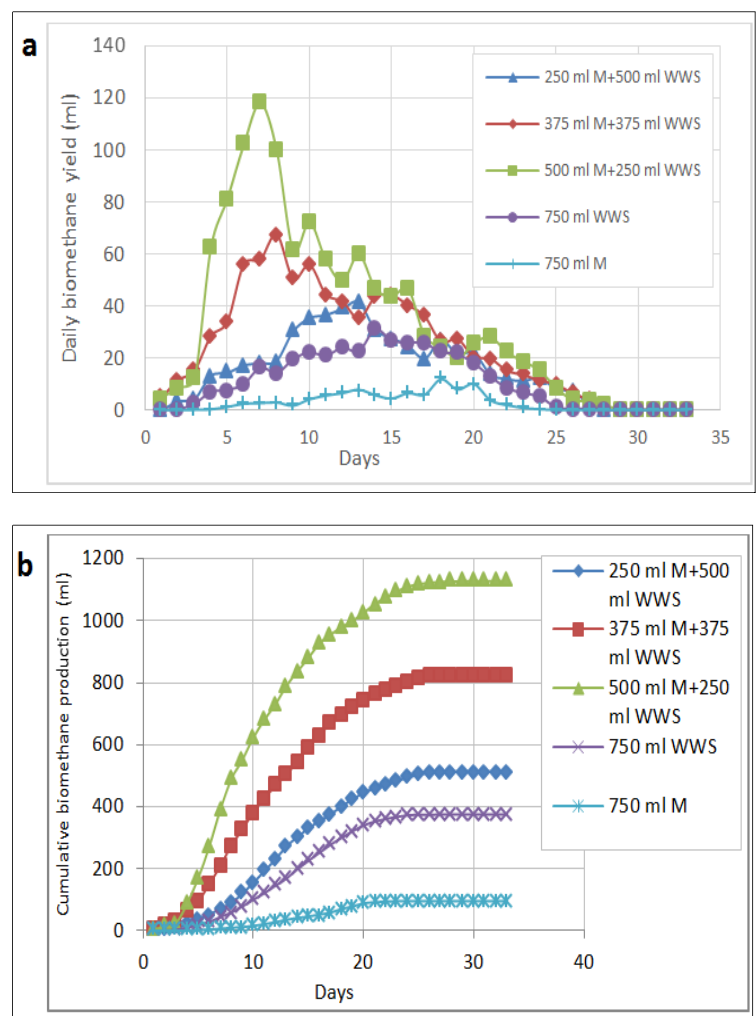

Fig. 7. Daily (a) and (b) Cumulative biomethane production (ml) for codigestion of Microalgae- 
Wastewater sludge (M+WWS) system.

Table 3,

Total biogas and methane yields from microalgaewastewater sludge system at day-30.

\begin{tabular}{llll}
\hline $\begin{array}{l}\text { System } \\
\text { composition } \\
\text { M: Microalgae } \\
\text { DMW: Dairy } \\
\text { manure waste }\end{array}$ & $\begin{array}{l}\text { Total } \\
\text { biogas } \\
\text { volume } \\
(\mathbf{m l})\end{array}$ & $\begin{array}{l}\text { Methane } \\
\text { volume } \\
(\mathbf{m l})\end{array}$ & $\begin{array}{l}\text { Methane } \\
\%\end{array}$ \\
\hline $750 \mathrm{ml}$ M & 943 & 513.272 & 67.8 \\
$750 \mathrm{ml}$ DMW & 1693 & 821.916 & 62 \\
$\begin{array}{l}250 \mathrm{ml} \text { M + 500 } \\
\mathrm{ml} \text { DMW }\end{array}$ & 2590 & 1127.69 & 61.6 \\
$\begin{array}{l}\text { 375 ml M + 375 } \\
\text { ml DMW }\end{array}$ & 697 & 374.956 & 63.8 \\
$\begin{array}{l}500 \mathrm{ml} \text { M + 250 } \\
\text { ml DMW }\end{array}$ & 147 & 95.31 & 54 \\
\hline
\end{tabular}

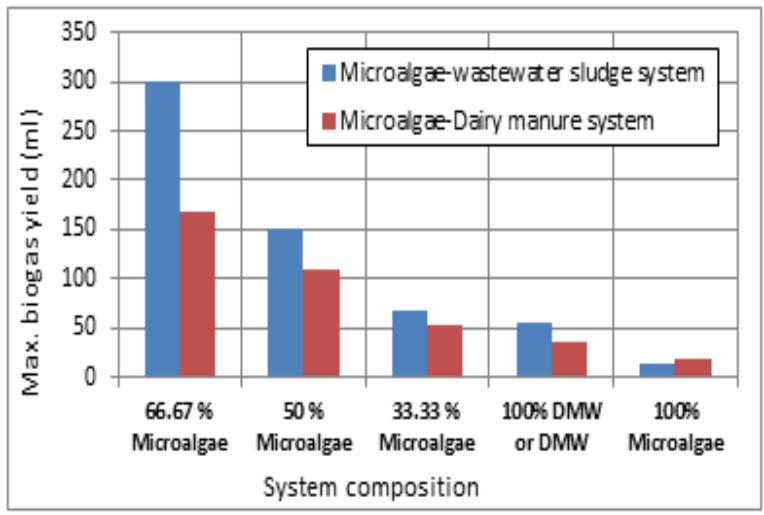

Fig. 8. Comparison between max daily biogas yield of Microalgae-Wastewater sludge and Microalgae-Dairy manure waste systems.

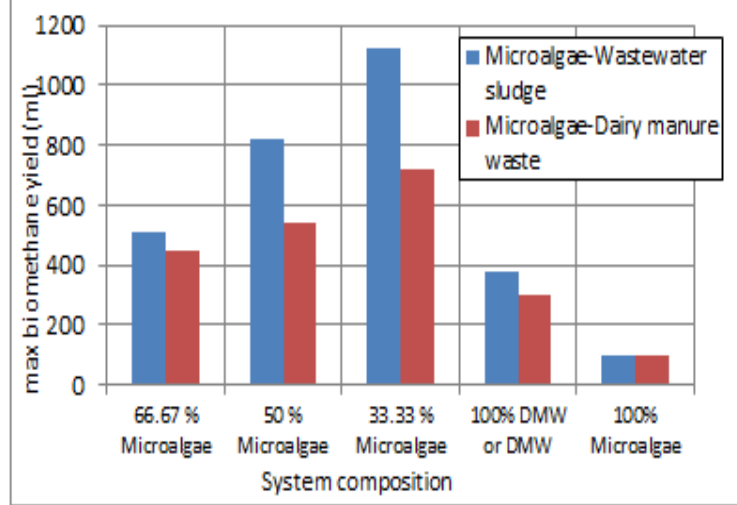

Fig. 9. Comparison between max biomethane yield of Microalgae-Wastewater sludge and Microalgae-Dairy manure waste systems.

\subsection{Microalgae -Dairy Manure Waste- Wastewater Sludge System}

Figs. 10 and 11 show the daily biogas volume and cumulative biogas respectively produced from system contain $500 \mathrm{ml}$ microalgae, $125 \mathrm{ml}$ wastewater sludge and 125 $\mathrm{ml}$ wastewater sludge. Fig. 11 shows the daily methane production for the same system. The maximum biogas yield was recorded as $162 \mathrm{ml}$ at the $8^{\text {th }}$ day while the maximum biomethane yield was $80.46 \mathrm{ml}$ achieved also at the $8^{\text {th }}$ day of codigestion.
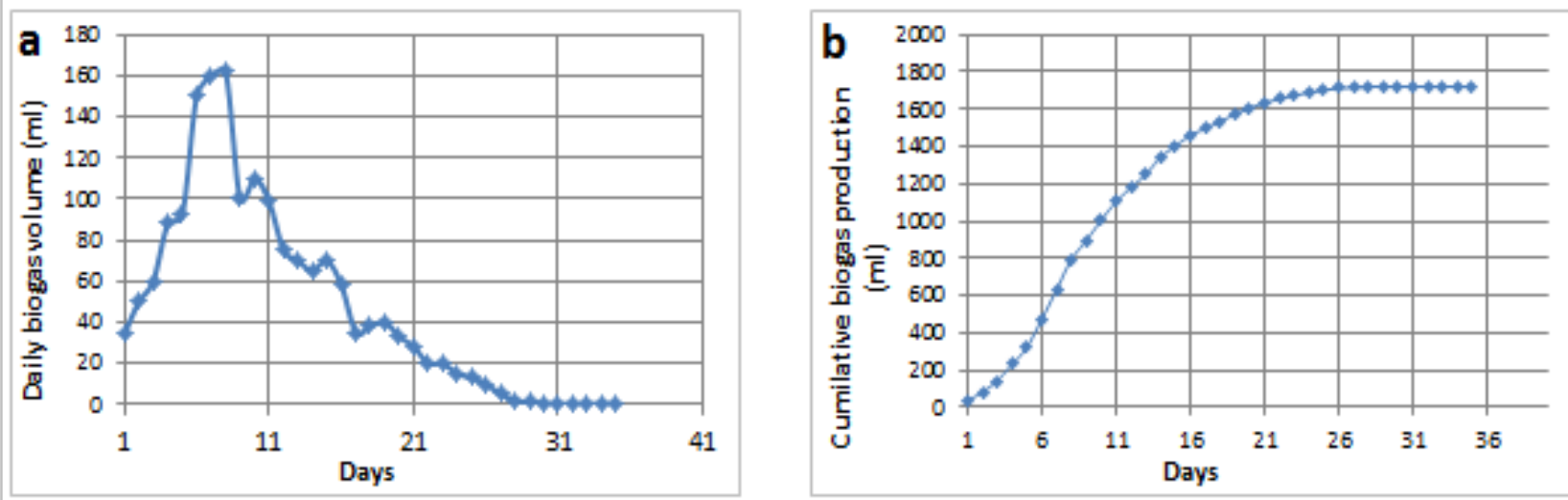

Fig. 10. Daly (a) and Cumulative (b) biogas production for microalgae, Dairy manure waste and wastewater sludge (500 ml M+125 ml DMW+125 ml WWS) system 


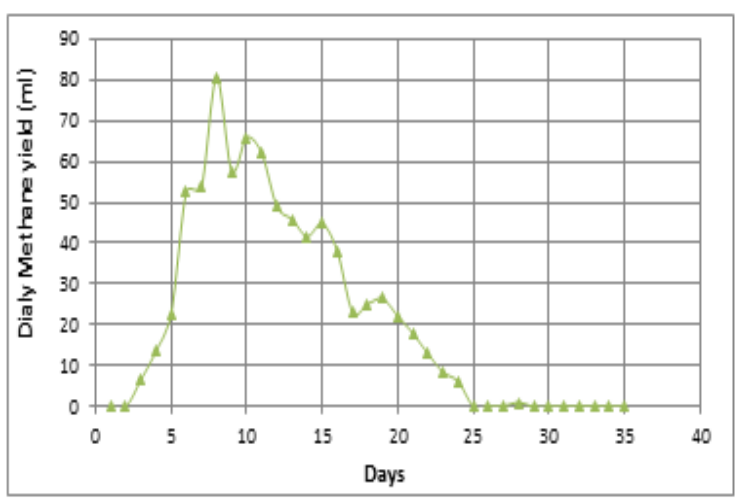

Fig. 11. Daily biomethane production (ml) for codigestion of Microalgae-Wastewater sludgeDairy manure waste system

It's known that biomethane production curves are often divided into three stages: Lag phase, decomposition phase and flattening phase [14]. The lag phase is the time from the start of the experiment to the start of the biomethane production in the bioreactors. It can be seen in all Figures that there is no clear lag phase for the bottles with high microalgae content but a short lag phase for the bottles with low microalgae content.

\section{Conclusions}

This study was performed to assess the biomethane generation potential from codigestion of microalgae Chlorella Vulgaris biomass with two extra carbon source including wastewater sludge and dairy manure waste to overcome the problem of low $\mathrm{C} / \mathrm{N}$ ratio in microalgae. By comparing the single digestion with codigestion of combined wastes, the codigestion resulted in higher biogas yields and also had a positive effect on the methane content of the biogas produced due to positive synergisms established in the digestion medium. Microalgae-wastewater sludge system was give higher biogas yield than microalgae-dairy manure waste at the same proportions.

\section{Notation}

$\begin{array}{ll}\mathrm{C} & \text { Carbone } \\ \mathrm{N} & \text { Nitrogen } \\ \mathrm{C} / \mathrm{N} & \text { Carbone to Nitrogen ratio } \\ \text { NPK } & \text { Nitrogen-Phosphor-Potassium }\end{array}$

$\begin{array}{ll}\text { DMW } & \text { Dairy manure waste } \\ \text { M } & \text { Microalgae } \\ \text { WWS } & \text { Wastewater sludge }\end{array}$

\section{Acknowledgement}

This work is part of final year graduation project. The support provided by chemical engineering department is greatly acknowledged. The authors also acknowledge the staff of The Ministry of Science and Technology / Environment and Water Department, Baghdad (Iraq) for providing wastewater sludge and their support.

\section{References}

[1] Williams, C. L., Willard, S., Kouba, A., Sparks, D., Holmes, W., Falcone, J. \& Brown, A. "Dietary shifts affect the gastrointestinal microflora of the giant panda (Ailuropodamelanoleuca)". Journal of animal physiology and animal nutrition, 97(3), 577585, (2013).

[2] Ward, A. J., Lewis, D. M., \& Green, F. B. "Anaerobic digestion of algae biomass: a review." Algal Research, 5, 204-214, (2014).

[3] Prakash, N. B., Sockan, V., \&Jayakaran, P. "Mathematical model development for BOD removal efficiency in tannery waste treatment ". British Journal of Environmental Sciences, 3(1), 1-12, (2015).

[4] Wu, W. "Anaerobic co-digestion of biomass for methane production: recent research achievements". Optimization, 1, 1VS, (2007).

[5] Kangle, K. M., Kore, S. V., Kore, V. S., \&Kulkarni, G. S. "Recent trends in anaerobic codigestion: a review". Universal Journal of Environmental Research and Technology, 2(4), 210-219, (2012).

[6] Mata-Alvarez, J., Dosta, J., Macé, S., \&Astals, S. "Codigestion of solid wastes: a review of its uses and perspectives including modeling." Critical reviews in biotechnology, 31(2), 99-111, (2011).

[7] Salerno, M., Nurdogan, Y., \& Lundquist, T. J. "Biogas production from algae biomass harvested at wastewater treatment pond"s ( $p$. 18). American Society of Agricultural and Biological Engineers, (2009). 
[8] Sialve, B., Bernet, N., \& Bernard, O. "Anaerobic digestion of microalgae as a necessary step to make microalgal biodiesel sustainable". Biotechnology advances, 27(4), 409-416, (2009).

[9] Golueke, C. G., Oswald, W. J., \&Gotaas, H. B. "Anaerobic digestion of algae". Applied microbiology, 5(1), 47, (1957).

[10] Yen, H. W., \&Brune, D. E. "Anaerobic codigestion of algal sludge and waste paper to produce methane". Bioresource technology, 98(1), 130-134, (2007).

[11] Chen, Y., Cheng, J. J., \& Creamer, K. S. "Inhibition of anaerobic digestion process: a review". Bioresource technology, 99(10), 4044-4064, (2008).
[12] Samson, R., \&LeDuy, A. "Improved performance of anaerobic digestion of Spirulina maxima algal biomass by addition of carbon-rich wastes." Biotechnology letters, 5(10), 677-682, (1983).

[13] Ammar Saad H. "Cultivation of Microalgae Chlorella vulgaris in airlift photobioreactor for Biomass Production using commercial NPK nutrients". Al-Khwarizmi Engineering Journal, 12(1), p.90-99, (2016)

[14] Olsson, J., Feng, X. M., Ascue, J., Gentili, F. G., Shabiimam, M. A., Nehrenheim, E., \&Thorin, E. "Co-digestion of cultivated microalgae and sewage sludge from municipal waste water treatment". Bioresource technology, 171, 203-210, (2014). 


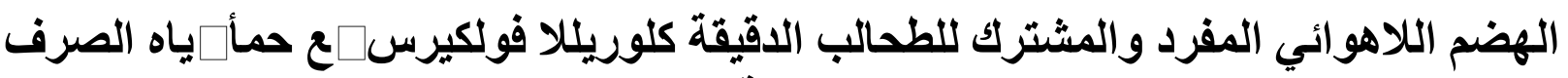 الصحي وزخلفات الماثشية لانتاج الغاز الحيوي
}

\author{
***ن \\ سعد حنش عمار

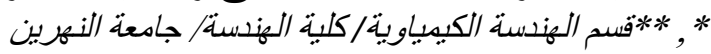 \\ *البريد الإكتروني: \\ Sadqkn@gmail.com البريد الاككتروني:
}

عملية الهضم اللاهو ائي للمو اد العضوية هي عملية تفكك كيميائية حيوية تتم بوساطة نو عين من البكتريا الهاضمة بغياب الاوكسجين منتجة الغاز الحيوي

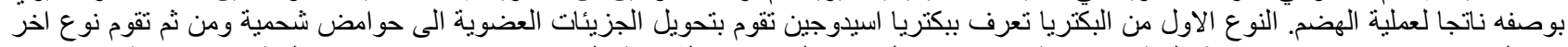

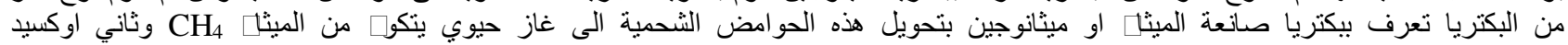

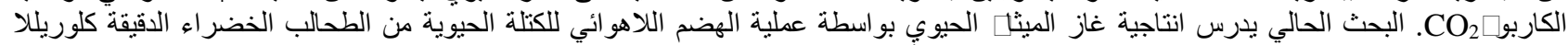

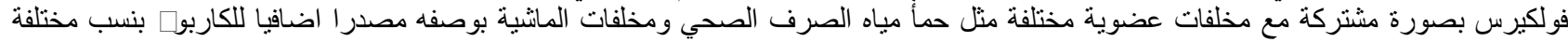

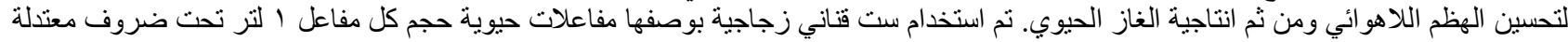

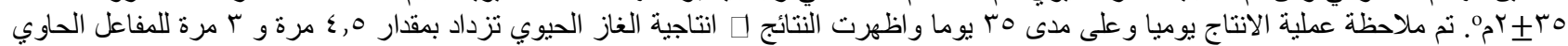

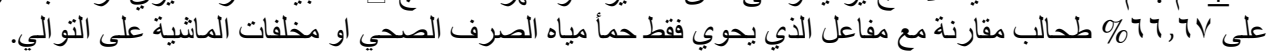

